Western University Scholarship@Western

Political Economy Research Group. Papers in

Political Economy

Economics Working Papers Archive

1993

\title{
Belgium: From Regionalism to Federalism
}

Liesbet Hooghe

Follow this and additional works at: https://ir.lib.uwo.ca/economicsperg_ppe

Part of the Economics Commons

Citation of this paper:

Hooghe, Liesbet. "Belgium: From Regionalism to Federalism." Political Economy Research Group. Papers in Political Economy, 43. London, ON: Department of Economics, University of Western Ontario (1993). 
POLITICAL

ECONOMY

RESEARCH

GROUP

\section{PAPERS IN POLITICAL ECONOMY}

Paper No. 43

$\$ 37704$

"Belgium: From Regionalism to Federalism"

Liesbet Hooghe

\section{MAR 181994}


The Political Economy Research Group was established in the faculty' of Social Science at the University of Wéstern Ontario in 1988. Its purpose is to foster scholarship, teaching and interdisciplinary research in political economy, with - a focus on:

1. the application of economic models and methods to the stydy of political processes and institutions,

2. the economic impact of political processes and institutions,

3. the influence of economic factors on the formation of public policy and on institutional change,

4. the politics of economic policy making,

5. the political, social, and economic effects of public policy.

Co-directórs:

Ronald Wintrobe (Economics)

Robert'Young (Political Science)

Board of Directors:

Peter Howitt (Economics)

B.B. Kymlicka (Political Science)

John N. McDougall (Political Science)

Peter Neary (History)

John Whalley (Economics)

Staff:

Jayne Dewar

For further information:

Political Economy Research Group,

Department of Economics,

-Social Science Centre,

London, Ontario, Canada N6A 5C2

phone: (519) 661-3877

) $\therefore$ fax: (519) 661-3292 
ISSN: $1181-7151$

ISBN: $\quad 0-7714-1638-5$

\title{
Belgium: From Regionalism to Federalism
}

\author{
LIESBET HOOGHE
}

\section{INTRODUCTION}

Ethnic conflict in Belgium has been intense, but peaceful. Its roots are linguistic: a majority of the population speaks Dutch, but the official language in the nineteenth century was French. Ethnic demands and conflict management strategies were initially non-territorial, but increasingly acquired a territorial aspect. The fact that Dutch and French speakers were to a large extent territorially segregated facilitated this evolution. At a later stage, ethnic conflict also acquired a socio-economic dimension. The increased territorial emphasis in ethno-linguistic politics had made the emergence of economic ethno-nationalism easier and was in its turn reinforced by these later developments.

But the issue is more complex; each of the two forms of nationalism demanded a slightly different type of territorial settlement. This made the ethnic challenge ambivalent in two ways. First, language and socioeconomic interests were treated as separate criteria in drawing and redrawing boundaries. Which was to have priority? Second, the two were to some extent contradictory. Was a territorial solution really the better choice for the management of ethnic conflict in Belgium? This ambiguity gave ammunition to those who sought to postpone or prevent territorial devolution.

Hence, political actors in Belgium had considerable leeway in dealing with the ethnic issue. This leeway was a consequence of the structure of the conflict, and the actors used it to their political advantage. Thus they were likely to change definitions of the groups-in-conflict when political opportunities altered. Furthermore, actors who favoured a territorial position on one occasion might be found to take a much less radical or even a non-territorial stand in another situation. Put differently, political actors in Belgium were prepared to draw and redraw boundaries such that inter-group contact was lessened, but only when it was to their advantage.

This contribution starts with a short historical introduction and data on the current ethno-linguistic balance. It continues with an analysis of the principal sources of ethnic conflict and change over time. The following

This paper appeared in Regional Politics and Policy, 3:1, 1993. 
section tries to show why the territorial approach became the dominant strategy for conflict management and how Belgium evolved from regionalism to federalism. Finally, this approach is placed in a broader context of political conflict management in Belgium. It is argued that federalism is an attempt to continue the traditional consociational approach by other means, but that the legacy of consociationalism makes this a risky enterprise.

\section{EMERGENCE OF THE ETHNIC PROBLEM}

Belgium was created in 1830 when it seceded from the Netherlands after only 15 years of union. The national question in Belgium was initially defined as a language issue. Cultural deprivation spurred a Flemish movement, whose roots are to be found already in the nineteenth century. After 1945 divergent economic developments between north and south gave rise to a genuine Walloon nationalism. Finally, in the 1960 s and 1970s the lines of conflict converged in and around Brussels, where a Francophone 'nationalist' movement became articulate.'

These different types of nationalism developed against the background of early industrialization and liberal democracy on the one hand and relatively late mass democracy on the other hand. This had important consequences. First, nationalism and the emergence of a modern society evolved quite independently in Belgium. In many European countries nationalist movements were pivotal in the break-up of the old regime and the diffusion of liberal democratic ideas. The Belgian state, however, was created by a coalition between traditional groups (nobility or landowners, and the Catholic Church) and new middle classes (industrialists and the intelligentsia). When this coalition broke down shortly after independence, politics rapidly became competitive. Nation-wide political parties were formed along the conservative (or, more precisely, Catholic) - liberal cleavage. Put differently, modern political cleavages and modern politics came first; nationalist movements appeared afterwards. New middle classes in search of political incorporation turned more readily to politics defined by the conventional liberal-Catholic or capital-labour cleavage than to nationalism. Hence nationalist movements took root only slowly in Belgian political life, and the older cleavages continued to cause divisions within them.

Second, the retarded breakthrough of mass democracy inhibited popular mobilization on the nationalist issue. Suffrage was limited to the upper classes until the last decade of the nineteenth century; the first elections according to the 'one man, one vote' principle were held in 1919.' 
Third, the combination of early liberal democracy and late transition to mass democracy influenced the agenda of the early nationalist movements and has marked nationalist conflict to this day. Nationalists had little chance of becoming the major advocates of civil rights or social rights and democratization, let alone of monopolizing these issues. Civil rights and the liberal secular state were defended by the Liberal Party since the creation of Belgium. ${ }^{3}$ Universal suffrage and better labour conditions were advanced by left-wing elements within the two traditional parties, and from the 1880 s onwards also by a small socialist party. Nationalists played only a marginal role in this debate, especially since social and cultural grievances did not coincide geographically. The social class cleavage was most salient in Wallonia, which was assimilated fairly smoothly to the Francophone culture of the Belgian state; the capitallabour conflict was much weaker in rural, Dutch-speaking Flanders.

Flemish nationalism was provoked by language grievances and remained very weak on the labour and agrarian issues throughout the nineteenth century. This thwarted mass mobilization. However, the small group of Flemish nationalists, most of them intellectuals or members of the higher middle class, ${ }^{4}$ was successful in its narrow political agenda: by the end of the nineteenth century Dutch was accepted in Flemish public life and gradually replaced French in Flanders. Flemish nationalism 'imagined its community"s predominantly along culturallinguistic lines. When universal suffrage was introduced, the Flemish nationalists again failed to reap the expanded mobilization potential. Democratization strengthened the Belgian Socialist Party and the Christian Democratic labour wing in the Belgian Catholic Party instead, groups that monopolized the socio-economic cleavage. ${ }^{6}$ But democratization was also a deathblow for unilingually Francophone Belgium: a Flemish public life. complete with its own elite, emerged parallel to the Francophone one. Flemish nationalists had been demanding this since the $1850 \mathrm{~s}$, and have continued to imagine their community mainly in terms of these successful cultural-linguistic criteria.

After 1945 the industrial decline of Wallonia became apparent, and this sharpened Walloon regional consciousness (as distinct from a consciousness based on language). Walloon nationalism imagined its community primarily along socio-economic lines, and continues to do so.

\section{THE ETHNO-LINGUISTIC BALANCE}

In the Belgian census of 184642.1 per cent reported French as the language they spoke most frequently, 57.0 per cent Dutch and 0.8 per cent German.' In the Flemish provinces two to four per cent reportedly 
TABLE I

BELGIUM: LINGUISTIC COMPOSITION BY REGION. 1947

\begin{tabular}{|c|c|c|c|c|c|c|c|c|}
\hline Lenguage & $\begin{array}{l}\text { Flander } \\
\text { coos }\end{array}$ & ${ }^{23}$ & $\begin{array}{l}\text { Wallonia } \\
\text { coos }\end{array}$ & $\%$ & $\begin{array}{l}\text { Brusset } \\
\text { coos }\end{array}$ & * & $\begin{array}{l}\text { Belgium } \\
000 \text { s }\end{array}$ & $\$$ \\
\hline $\begin{array}{l}\text { Dutch } \\
\text { French } \\
\text { Cerman } \\
\text { Unknown }\end{array}$ & $\begin{array}{r}4.184 .0 \\
225.4 \\
8.2 \\
198.6\end{array}$ & $\begin{array}{r}90.4 \\
4.9 \\
0.2 \\
4.3\end{array}$ & $\begin{array}{r}59.5 \\
2.671 .2 \\
67.0 \\
145.4\end{array}$ & $\begin{array}{r}2.0 \\
90.8 \\
2.3 \\
4.9\end{array}$ & $\begin{array}{r}231.7 \\
675.0 \\
3.4 \\
45.9\end{array}$ & $\begin{array}{r}24.2 \\
70.6 \\
0.4 \\
4.8\end{array}$ & $\begin{array}{r}4.475 .2 \\
3.571 .6 \\
78.6 \\
389.9\end{array}$ & $\begin{array}{r}52.6 \\
41.9 \\
0.9 \\
4.6\end{array}$ \\
\hline Toual & $4,616.2$ & 100.0 & $2,943.1$ & 100.0 & $9,560.0$ & 100.0 & $8,515.3$ & 100.0 \\
\hline
\end{tabular}

Note: Respondents were asked which language they spoke only or most frequently. Absolute figures are in thousands. More than 80 per cent of the 'unknown' category were infants under two years of age; if included, the linguistic composition would be something like 55 per cent Dutch-speaking and 44 per cent French-speaking.

Source: Computed by the author from Nationaal Instituut voor de Statistiek (NIS), Algemene Volkstelling op 31 december 1947: indeling naar de gesproken landstalen (Brussels: NIS, 1954), pp.58-63. 72-3, 152-3.

spoke French only (most of these belonged to the upper classes). ${ }^{8}$ The most recent official figures on language usage date from the census of 1947 , and demonstrate how little the situation had changed by then. Its general findings are reported in Table 1 . It may be seen that Flanders and Wallonia were to a large extent linguistically homogeneous in 1947, especially when the 'unknowns' (most of them infants under two years) are disregarded. The five per cent Francophone minority in Flanders was widely dispersed. However, critical masses were to be found in large cities (notably Antwerp, Ghent, Bruges and Louvain) and in some villages along the border with France or Wallonia. Detailed studies of their socio-economic background are lacking, but most Francophones reportedly belonged to the aristocracy; the upper bourgeoisie or the liberal professions." In Wallonia, the most sizeable minority in 1947 was German speaking. The great majority of this group was to be found in the so-called East Cantons. which were acquired from Germany after the First World War. The Flemish minority in Wallonia consisted mostly of immigrants of lower economic status in a process of cultural assimilation. By contrast to the two larger regions, Brussels (within its current boundaries) had undergone significant changes since Belgian independence. Until well into the nineteenth century the Brussels area was predominantly Dutch speaking, but with urbanisation and expansion Dutch was rapidly losing ground to French, which had clearly overtaken Dutch by 1947 .

Language usage became a sensitive issue after 1947, to such a degree that subsequent population censuses no longer provided data in this area. It is therefore a rather risky enterprise to assess the current linguistic balance in the three regions. Linguistic homogeneity has undoubtedly 
increased in Flanders and Wallonia, and, of equal importance, the formally unilingual character of the two regions is no longer a political issue. This is to a large extent the result of the language law of 1963 (see below), which transferred 25 communes (with some 87,000 inhabitants) from Flanders to Wallonia, and 24 communes (with some 24,000 inhabitants) in the opposite direction. Many more meticulously defined bits of territory were transferred one way or the other across the linguistic border. The development of mass society also stimulated homogenisation. In Wallonia, the Flemish immigrants quickly integrated. In Flanders, most Francophone families of elite backgrounds quietly adjusted to the change of language patterns: Dutch has become their working language, but their cultural identity seems to have remained primarily French-orientated. The one significant exception concerns Flemish municipalities adjacent to Brussels, where the Francophone presence has undoubtedly increased since the last census.

Language usage is still a sensitive question in and around the Brussels region. Many efforts were made to develop alternative measures of language use.$^{10}$ None of them seems to be reliable, although it is clear that verfransing, or assimilation to French culture, has continued in Brussels since 1947. Current estimates of the proportion of Dutch speakers fluctuate between 10 and 20 per cent for the 19 municipalities that constitute the Brussels Capital region. A figure somewhere in between these is indicated by the results of the first direct election of the regional council of Brussels Capital region in June 1989, when the Dutch-speaking lists obtained 15.3 per cent of the votes; all parties had been required to submit unilingual lists.

\section{PRINCIPAL SOURCES OF INTER-ETHNIC TENSION}

Inter-ethnic conflict in Belgium does not resemble a simple two-actor game. There are three major games, each with a limited number of parties involved: Flemish nationalism versus the Francophones on cultural identity, Walloon nationalism versus Flanders and Brussels on socio-economic grievances, and (Francophone) Brussels versus the rest of the country on centre-periphery matters. Each game is played by more-or-less distinctly defined actors. But the distinctions are small, making it hard to keep the games separate all the time. A singular feature of Belgian ethnic politics is that the three games collapse regularly into a single game in which the number of actors may vary from time to time.

Flemish Nationalism

While the constitution of 1831 guaranteed linguistic liberty. French became the only official language." Soon after independence, however, 
some intellectuals in the Flemish provinces began to advance language grievances. ${ }^{12}$ The first issues were purely linguistic and literary, but gradually the language grievances reached out to broader aspects of social life. Under Flemish pressure, language policy in Belgium evolved gradually from laissez-faire to language planning.

The first series of language laws of the late nineteenth cęntury imposed asymmetrical bilingualism. ${ }^{13}$ Flanders became bilingual, while the rest of the country remained unilingual. The legislation was limited in scope. The most important act symbolically was the Equalization Act of 1898 , which made Dutch an official language on equal footing with French."

The second wave of language laws, adopted in the 1930s, moved towards territorial unilingualism in Flanders and Wallonia and bilingual institutions in Brussels and in areas with linguistic minorities. The laws were more all-encompassing than their nineteenth century predecessors. The switch to territorial unilingualism allowed Flemings and Francophones (and especially French-speaking Walloons) to preserve their interests. Many Flemings feared that French would remain a highly attractive language for the leading classes in Flanders. The spread of French as 'the language spoken only or most frequently', in the terminology of the census reports, reached a maximum in the 1920s and 1930s: between six and 14 per cent in the urban centres of Flanders. ${ }^{\text {is }}$ Territorial unilingualism was to isolate this small, but strategic. Francophone minority in Flanders from Brussels and Wallonia. Walloons and Francophone Brussels residents feared that the alternative to territorial unilingualism, nation-wide bilingualism, would take jobs away from Francophones because of their poor knowledge of Dutch. Territorial unilingualism secured the essential: a unilingual Wallonia.

After the core law of 1932, which regulated the use of languages in the administration and in its dealings with the public, parliament passed language laws on education. judicial matters and the army. The different pieces of legislation rested on the same broad principles. First, official unilingualism was introduced in Flanders and Wallonia, but the boundaries could be adjusted after each language census. Municipalities with a significant official language minority offered certain public services in the minority language. Second, the general rule for the central public service was bilingualism of services but unilingualism of employees. Unilingual working units were created where possible, in order to restrict the number of bilingual positions. Third, Brussels was declared bilingual.

The law of 1932 and others in the 1930s were pivotal in transforming Flemish society into a Dutch-speaking community with a Dutch-speaking elite. ${ }^{10}$ Flemish nationalists now perceived a Francophone threat on their boundaries. After each language census some Flemish territory was lost, 
especially around Brussels. In 1960-61 the language questions in the census were boycotted on a large scale by Flemish local government authorities.

These grievances, along with gaps in the previous language laws, led to the last series of laws, which were passed in the 1960s. They refined and hardened territorial unilingualism. Most significant was the 1963 law, which divided Belgium into four language areas: unilingually Dutchspeaking (Flanders), unilingually French-speaking (Wallonia) and unilingually German-speaking areas, and the bilingual area of Brussels. ${ }^{17}$ Some municipalities on the two sides of the Flemish-Walloon border, six communes around Brussels and the German-speaking area retained some limited bilingual facilities. The 1963 law froze the linguistic frontier between Dutch-speaking Belgium, French-speaking Belgium and bilingual Belgium. But many Francophones have never accepted the freezing of the linguistic frontier around Brussels. The other contested area is Voeren, a conglomerate of six villages of altogether 5,000 inhabitants, the majority of whom now speak French, which was transferred from Wallonia to Flanders.

In the process of interaction with the Belgian-Francophone state and the emerging Francophone-Walloon movement the Flemish movement became nationalist. After the First World War cultural autonomy became the most urgent demand of the nationalist movement. In 1919 a genuine Flemish nationalist party, the Frontpartij, gained its first electoral success. It was succeeded in the 1930 s by the Vlaams Nationaal Verbond (VNV). Its success forced the Catholic Party in Flanders to support demands for some form of cultural autonomy. Several Flemish nationalist leaders collaborated with the German occupiers during the Second World War. The Flemish movement made a fresh start in 1954, when a new Flemish party, the Volksunie (VU), entered parliament on a federalisi platform. However, its breakthrough came only in 1965 . The VU obtained its highest share of the vote in 1971 with 19.4 per cent of the Flemish vote. The success of the Flemish nationalists at the polls gradually heightened Flemish-Francophone tensions in the traditional parties, which split along linguistic lines after 1968. The Flemish Christian Democrats and Socialists wrote federalism into their party programmes in the 1980s, while the Liberals remained more reluctant. The VU was damaged by this co-optation of their primary issue, and it has been declining since then, obtaining its lowest result since 1965 in the November 1991 parliamentary elections: a mere 9.5 per cent of the Flemish vote. The VU also suffered from the defection of more extreme elements: in 1978, a breakaway group, the Vlaams Blok. entered parliament on a separatist platform. Although this group has since moved to the extreme 
TABLE 2

BELGIUM: EVOLUTION OF GROSS DOMESTIC PRODUCT AND GROSS REGIONAL PRODUCT. 1955-88

\begin{tabular}{|c|c|c|c|c|c|c|}
\hline Yess & Flanders & Wallonia & Brussels & Flanders & Wallonia & Brussels \\
\hline & \multicolumn{2}{|c|}{ Share of GDP } & \multicolumn{4}{|c|}{ CRP per capisa } \\
\hline \multirow[t]{2}{*}{$\begin{array}{l}1955 \\
1963 a \\
1963 b \\
1970 \\
1980 \\
1988\end{array}$} & $\begin{array}{l}44.2 \\
46.0 \\
49.8 \\
53.9 \\
56.9 \\
58.7\end{array}$ & $\begin{array}{l}34.2 \\
30.8 \\
31.3 \\
29.1 \\
27.6 \\
26.3\end{array}$ & $\begin{array}{l}21.6 \\
23.2 \\
18.9 \\
17.0 \\
15.5 \\
15.0\end{array}$ & $\begin{array}{r}87.3 \\
89.6 \\
90.0 \\
96.0 \\
99.6 \\
101.9\end{array}$ & $\begin{array}{r}100.6 \\
93.3 \\
93.2 \\
88.9 \\
84.4 \\
80.8\end{array}$ & $\begin{array}{l}140.8 \\
147.8 \\
169.7 \\
152.6 \\
152.4 \\
152.6\end{array}$ \\
\hline & \multicolumn{2}{|c|}{ Average growth of GRP } & & \multicolumn{3}{|c|}{ Average srowth of GRP per capita } \\
\hline $\begin{array}{l}1955-63 \\
1963-70 \\
1970-80 \\
1980-88\end{array}$ & $\begin{array}{l}3.9 \\
6.0 \\
4.0 \\
2.3\end{array}$ & $\begin{array}{l}2.2 \\
3.7 \\
3.3 \\
0.9\end{array}$ & $\begin{array}{l}4.3 \\
3.6 \\
1.8 \\
1.2\end{array}$ & $\begin{array}{l}3.1 \\
5.2 \\
3.7 \\
2.1\end{array}$ & $\begin{array}{l}1.9 \\
3.5 \\
3.1 \\
0.9\end{array}$ & $\begin{array}{l}3.3 \\
3.0 \\
2.5 \\
1.6\end{array}$ \\
\hline
\end{tabular}

Note: The data refer to the share of each region in Gross Domestic Product (GDP), Gross Regional Product $($ GRP) per head (national $=100$ ), average yearly growth of GRP and average yearly increase of GRP per head. The Brussels region was reduced in 1963 and Flemish territory was expanded; the two series of figures on 1963 refer to the positions before and after this change.

Source: Computed by the author from NIS. Statistische studienn, No.91 (Brussels: NIS, 1991), pp.76-83.

right, its support jumped from three per cent of the Flemish vote in 1987 to 10.6 per cent in $1991 .^{18}$

\section{Walloon Nationalism}

The breakthrough for Walloon nationalism came only after the Second World War. ${ }^{14}$ and was a reaction against Wallonia's economic decline in the twentieth century. The Walloon economy was dependent on the heavy steel and coal industries, which were rapidly losing importance after 1945. Light industry lagged behind in modernization or moved out of Wallonia and new industry tended to avoid the region. ${ }^{30}$

Uneven patterns of economic development and an increasingly negative demographic balance caused widespread resentment. First, Belgian high finance, which had made considerable profits in the heyday of Wallonia's industry, made few new investments and turned instead increasingly to Flanders. Flanders overtook Wallonia between 1963 and 1966 in terms of gross regional product (GRP) per capita (based on residence), and by the end of the 1980 s had established a considerable lead, as may be seen from Table 2 . Wallonia felt abandoned by high finance in Brussels and by Flanders.

Second, many Walloons were afraid of political domination by the 
TABLE 3

BELGIUM: DEMOGRAPHIC EVOLUTION. BY REGION, 1947-2025

\begin{tabular}{lrrrrr}
\hline Year & Flanders & Wallonia & $\begin{array}{l}\text { Cerman } \\
\text { Region }\end{array}$ & Brusects & Belgium \\
\hline 1947 & 4.551 .9 & 2.949 .5 & 54.8 & 955.9 & 8.512 .2 \\
& $(53.5)$ & $(34.6)$ & $(0.0)$ & $(11.2)$ & $(100.0)$ \\
1961 & 5.064 .0 & 3.045 .3 & 57.7 & 1.022 .8 & 9.189 .7 \\
& $(55.1)$ & $(33.1)$ & $(0.6)$ & $(11.1)$ & $(100.0)$ \\
1971 & 5.416 .6 & 3.101 .8 & 62.0 & 1.075 .1 & 9.650 .9 \\
& $(56.1)$ & $(32.1)$ & $(0.6)$ & $(11.1)$ & $(100.0)$ \\
1981 & 5.630 .1 & 3.156 .3 & 64.9 & 997.3 & 9.848 .6 \\
& $(57.2)$ & $(32.0)$ & $(0.7)$ & $(10.1)$ & $(100.0)$ \\
1991 & 5.768 .9 & 3.188 .1 & 67.6 & 954.0 & 9.978 .7 \\
& $(57.8)$ & $(31.9)$ & $(0.7)$ & $(9.6)$ & $(100.0)$ \\
Projections of NIS: & & & & & \\
2000 & $(58.9)$ & $(32.2)$ & & $(8.9)$ & $(100.0)$ \\
2025 & $(60.3)$ & $(31.5)$ & & $(8.2)$ & $(100.0)$ \\
\hline
\end{tabular}

Note: Absolute figures are in thousands; figures in brackets are percentages. The NIS projections for Wallonia include the German region.

Source: NIS, Volkstelling, 1947, 1961, 1971, 1981; Belgisch Staatsblad, 15 October 1991 (figures for 1991 census).

Flemings, because the latter held a majority of the seats in the national parliament." Table 3 shows that the Walloon population increased at a much slower pace than the Flemish. Until the 1970s this was mainly due to a significantly higher birth rate and higher life expectancy in Flanders. Although the two rates of natural increase have converged (the Flemish birth rate was even lower than the Walloon one for several years in the 1980s), it is expected that the share of Flanders in the total Belgian population will increase further due to earlier high birth rates in Flanders and to divergent migration patterns.

Walloons feared that in a unitary state the necessary restructuring of their economy would be done on Flemish terms. Political preferences in Wallonia have traditionally been more supportive of state intervention than in free market-oriented Flanders or Brussels. This was due to a larger socialist movement, but it can also be explained by divergences in the economic structure of the three regions. The general pattern of development was analogous in the two larger regions: near-disappearance of agriculture, decline of the industrial sector, and growth in the tertiary sector. In 1966 the industrial and tertiary sectors were almost equally important in terms of their contribution to the GRP of Wallonia ( 46 and 48 per cent respectively) and of Flanders ( 44 and 51 per cent). By 
1988 the tertiary sector accounted for 64 per cent in Wallonia and the secondary sector had dropped to 35 per cent. In Flanders the evolution had been less dramatic: 61 per cent for the tertiary sector and almost 39 per cent for industry. The standard of living in Brussels has traditionally been highly dependent on the tertiary sector ( 71 per cent in 1966; 84 per cent in 1988).

However, the evolution within each region was different. Walloon industrial production depended heavily on three subsectors (the metallurgical industry, iron and steel, and construction) and all three experienced abrupt recessions in the 1970s or 1980s. Flemish industrial production was more diversified, was more often based in advanced sectors (the car industry, the chemical industry and electronics) and did not experience comparable set-backs. Similarly, the tertiary sector has developed differently in the three regions. In Wallonia. growth was most pronounced in the services category (public services and education especially), from 24 per cent of GRP in 1965 to as much as 37.5 per cent in the 1980s. Increase in Flanders was more evenly spread over the different categories. In Brussels, financial services and insurance boomed; they accounted for more than 20 per cent of GRP in 1988. In a nutshell, tertiary growth in Flanders and Brussels depended more on private. initiative than in Wallonia."

The first serious challenge to the Belgian unitary state came from the Walloon movement. At a conference of all major Walloon and Francophone leaders in 1945 an overwhelming majority opted for an autonomous Wallonia in a federal Belgium. However, the dust settled quickly and very little changed. Walloon nationalist party formation did not take place until the 1960s. In 1961, a popular Walloon labour leader broke away from the socialist party. His popular movement, Mouvement populaire wallon, carried a radical federalist and socialist platform. Four years later two Walloon nationalist parties each won a seat in the national parliament. In 1968, a new party, the Rassemblement wallon (RW), suddenly won 11 per cent of the regional votes. However, in the 1980 s the RW became almost completely absorbed by the Francophone socialists (PS) and to a lesser extent the Christian Democrats. In the 1980s the PS endorsed a radical federalist programme for economic autonomy; the nationalist parties in Wallonia obtained less than two per cent of the regional vote in the elections of 1991.

The economic expansion programme of the 1950s and 1960s and subsequent decentralization of industrial policy and regional development in 1970 were in part a response to Walloon nationalist demands. The new structures respected the linguistic border between Flanders and Wallonia and became the first regional (as opposed to national) policy 
instruments. But genuine regional autonomy was not realized until the state reform of 1980 .

The Defensive Reaction of Brussels

In the 1960s and 1970s the Flemish and Walloon movements transferred the battle about the appropriate model of state structure to Brussels. although there was also an independent Brussels component. ${ }^{3}$ The two most significant features of the development of Brussels since independence are its expansion into the Flemish countryside and its becoming increasingly French-speaking. especially since the 1950s. Nearly one out of ten Belgians is an inhabitant of Brussels. 80 to 85 per cent of whose population are solidly French-speaking. Approximately a quarter of French-speaking Belgians live in Brussels, but fewer than three per cent of the Dutch-speaking Belgians do so.

As Flanders became solidly Dutch-speaking in the 1960s and 1970s, the Flemish movement shifted its attention to Brussels. It seemed a logical step, because the expansion and verfransing of Brussels echoed the earlier Francophone threat to Flemish culture in Flanders. The Flemish movement won the first round in the 1960s. Expansion was halted by the law on the freezing of the linguistic frontier in 1963. Creeping verfransing was made more difficult by the establishment of more rigid rules and more effective control mechanisms on the implementation of official bilingualism in the capital. But the Francophones reacted against this cordon and the restraints upon their majority position in the capital. Brussels produced its own Francophone nationalist movement. the Front démocratique des francophones (FDF, founded in 1964). which obtained at the height of its success in the 1970 s more than 35 per cent of the votes in the Brussels metropolitan area. By 1991. however, its support had been reduced to approximately 12 per cent.

Flemings and Francophones diverged on the appropriate institutions for bilingual Brussels and its place in the Belgian constitutional structure. The Francophones of Brussels favoured an autonomous Brussels region. They found support in the Walloon nationalist movement, which wanted to transform Belgium into a federation of three regions. The Flemish movement was reluctant to accept a tripartite federal model. In an autonomous Brussels region the Flemish minority would be cut off from Flanders, which might put pressure on them to assimilate. On the national level Flanders could be pushed into a permanent minority position by a Francophone Brussels region and a Francophone Walloon region. It argued instead for federalism hased on the two large communities.

Only in 1988 were Flemings and Francophones able to agree upon 
autonomous regional institutions for Brussels with special minority guarantees for the Flemish. The boundaries of the Brussels metropolitan area were confirmed without granting additional rights to the Francophones in the adjacent municipalities. However, for many Francophones from the Brussels area the debate is not closed.

\section{FROM REGIONALISM TO FEDERALISM}

The unitary state structure resisted ethnic pressure until 1970, when the government declared before parliament that 'the unitary state, its structure and functioning as laid down by law, had become obsolete'. ${ }^{44}$ Reform then came in three waves. In 1970 the existence of different territorial and cultural identities and the right to autonomy were constitutionally recognized. The second wave came in 1980 , when the state was regionalized. The third wave of 1988 federalized the country. However, the legacy of 150 year $s$ of interethnic competition and of unitary government has left its mark. Each state reform in Belgium is a contradictory combination of strong autonomist and strong unitarian tendencies.

Intergroup Conflict Recognized, 1970

The constitutional revision of 1970 was the first significant institutional response to regionalism (or nationalism). The modification of the unitary state followed two distinct tracks: regionalization on the one hand and acknowledgment of regionalist (or nationalist) aspirations in state-level institutions on the other. The reform attempted to protect the principle of unity of authority. which had for so long been characteristic of the Belgian state.

The first track concerned the recognition of the principle of language group rights at state level. The constitution entrenched four measures of power-sharing between the two language groups. First, from 1970 on the government was to consist of an equal number of Dutch-and Frenchspeaking ministers, taking decisions by consensus. Second, members of the national parliament were subdivided into separate Dutch and French language groups. Third, language policy legislation and certain constitutional laws were subjected to special voting requirements (the presence of a majority of each language group, support by a majority within each, and an overall two-thirds majority of yes-votes). Fourth, an 'alarm bell procedure' was approved: if 75 per cent of a language group judged a legislative proposal harmful to relations between the Dutch and French communities, the measure would be postponed and referred to the national cabinet.

On the other hand, two models of devolved government were en- 
trenched in the constitution: recognition was given to three distinct communities for cultural autonomy (French, Dutch and German) and to three regions for socio-economic autonomy (Flanders, Wallonia and Brussels). The proposed regional socio-economic autonomy was not implemented during the 1970 s, but a limited form of cultural autonomy was put into effect in 1971 with the establishment of cultural councils for the communities, each with its own executive.

This cultural devolution was peculiar. First, it was the language groups in the national parliament that acted as the communal legislative bodies; the cultural councils were not elected separately. Second, the community executives remained part of the national government, which collectively was still fully responsible for the implementation of cultural policy legislation. The communities thus did not get a separate administrative apparatus. ${ }^{25}$ Although Belgium gave up its formal unitary structure, the new system tried to maintain unity of authority by a conscious intertwining of central and regional/community levels. ${ }^{26}$ This conflict management tactic of blending these two levels in personal, institutional or policy domains was repeatedly tried out in later reforms.

\section{Regionalization in 1980}

The reform of 1980 opted more unambiguously for regionalization, rather than for adjustments within national institutions. The cultural communities gained new competences, the socio-economic regions were given institutional infrastructures and regional autonomy in general was strengthened. But nationalist pressures, as in 1970, pushed the reform in conflicting directions: regionalization preserved unitarian features, but at the same time adopted some federal or even confederal attributes. Both communities and regions obtained separate institutions, including a separate executive and civil service..$^{7}$

The regional reform of 1980 went beyond regionalization in several respects. First, the legislative acts of the regional and community councils had the same legal status as national laws. Second. Belgium opted for a dual form of regionalization. Most competences of regions, communities or the national state were exclusive instead of concurrent. Regionalization was also organized according to the vertical principle: legislative authority and execution or implementation were on the same level (amounting to jurisdictional rather than functional division of powers). Each level had its field of interest, which was reserved exclusively for it. This is different from Germany, where the federation often sets the broader legislative framework but leaves more detailed legislation and administrative implementation to the Länder. This combination of separate institutions. equal legal status, exclusive competences and juris- 
dictional division of labour was to create 'watertight compartments', designed to keep conflict low.

However, the concept of watertight compartments was unrealistic from the start. Central and regional levels remained entangled in several ways. First, direct election of the regional and community councils had been intended but this was not put into effect. The councils continued to consist of the members of the language groups in the national parliament, so that the same people exercised political control over national and regional executives. Second, the financial resources of the new structures, which were modest (less than ten per cent of public expenditure by 1988), came predominantly from block grants. Regions and communities had no significant financial responsibility. Third, policy areas were seldom allocated as a coherent whole to one level. A policy area was usually divided into thin slices, which were then distributed among two or three arenas (central state, community or region). Fourth, regionalization in Belgium combined constituent units based on the principle of territoriality (regional economy: two regions) and on the principle of nationality (language: three communities). Ethno-regional interests were thus institutionalized in two ways. ${ }^{28}$ This impeded the emergence of a unified regionalist counterforce. ${ }^{x}$ Thus the blending of central, community and regional levels not only restricted regional autonomy; it also forced the different arenas to consult or collaborate to render policymaking effective.

The 1980 reform combined efforts to segregate and equalize central and regional arenas with attempts to link them and maintain some hierarchy. The result was an unstable and destabilizing mechanism. The distribution of competences necessitated collaboration. but each arena's exclusive control over 'its' thin slice of a policy area complicated this. Furthermore, the divergent forms of institutionalization of regionalist interests made it unlikely that regionalism would become an unequivocal opposition force against the centre. Ethno-regionalist forces were divided: communities and regions overlapped, while Flemings, Walloons and Bruxellois disagreed on whether the territorial or the nationality principle should take priority. These clashes contaminated the central level, especially because central decision-making was itself divided along language lines.

\section{Federalization in 1988-89}

The reform of 1988-89 attempted to strike a new balance between centrifugal and centripetal tensions by opting for federalization. But similar tensions were built into the new model: a process of cooperative federalism was promoted in a constitutional framework of predominantly 
dual federalism (with exclusive competences and jurisdictional division of labour).

The reform gave effect to a considerable transfer of powers, with a division of labour between the federal level and the constituent units of the federation (community, region). A distinction can be made in the policy arena between micro-economic allocation, macro-economic stabilization and redistribution functions of government. Allocation refers to the normative framework for economic and social interaction on the one hand and for the delivery of public goods on the other. Stabilization focuses on the manipulation of inflation. employment and economic growth levels through budgetary. fiscal and monetary policy. Finally, the government plays a role in the restriction of welfare disparities by way of its redistributive policy." The second part of the allocative function. delivery of public goods, was almost completely transferred to regions and communities. The latter took over part of the normative framework, but the greater portion outside the cultural domain remained federal (or is being taken over by the European Community). Communities or regions would now, for instance. subsidize cultural events, organize and pay for education, invest in a cleaner environment (within national and European norms), undertake public housing, and seek to attract industrial investment (within ceilings for aid or subsidies set at the federal and the European levels). " The federal level retained control over the largest public utilities (such as the railways. telecommunications, postal services, the national airline, nuclear power plants and electricity). Stabilization policy remained federal, but an increasing number of decisions have been transferred to the EC. Redistribution (meaning. in effect. social security) continued to be fully federal. The net effect was that approximately one third of the national budget came under the control of the regions and communities.

The state reform of 1988-89 opted for a more systematic implementation of the dual federalism ('two worlds') model than that of 1980 . The first component of dual federalism - exclusive competences being preferred to concurrent competences - was made more explicit than in 1980. The policy packages for federal government, regions and communities were larger and more carefully defined. Very few competences were made concurrent, thus limiting opportunities for the federal level to interfere with the regions and communities or vice versa.

On the other hand. the reform did not try to create impeccably watertight compartments. On the contrary, it attempted not to apply too strictly the second component of dual federalism, jurisdictional rather than functional division of power. The federal government in principle kept control over the general legislative and fiscal framework. while more 
detailed legislative and executive work was transferred to regions and communities. Thus the latter obtained no powers over tax scales and tax base (in other words, no fiscal autonomy), and financial autonomy was limited. "The modest functional division of labour between general and specific legislative powers was applied to economic and social policy and to some regional matters (such as environmental protection). In addition, federal and regional policy and politics were unlikely to be in watertight compartments for much the same constitutional reasons as in 1980: the existence of three arenas with fluctuating territorial demarcations, overlap in the parcelling out of competences (although less than in 1980), and the fact that regional and community councils were composed of national parliamentarians rather than being elected separately. Finally, the mechanisms that were introduced in 1970 to recognize language group rights in national institutions remained in place: two language groups in the national parliament, special majority requirements, the 'alarm bell' procedure, and linguistic parity in the cabinet. These measures maintained an additional link between federal and regional politics.

Relations between different levels of government were thus bound to be extensive, and effective policy-making would necessitate mechanisms for cooperation. The state reform of 1988-89 created a deliberative structure to stimulate a cooperative federal process. The formal structure is influenced by the traditional concern for autonomy; concern for participation in decision-making comes second. Inter-level consultation was seen as a matter for executive agencies. The central institution for federal - regional - community relations is the Deliberation Committee (Overlegorgaan or Comite de concertation). The composition of the 12 member committee conforms to the 'double parity' rule: parity between federal and community/regional levels, and between Dutch and French speakers. ${ }^{33}$ In 1989 the general Deliberation Committee set up 15 Interministerial Conferences (IMCs), which bring together field ministers. Each IMC could set up working groups or commissions for preparatory activities or technical decision-making and was authorized to conclude collaboration agreements.

The concern for group autonomy rather than individual participation at the different levels was further reflected in other features of the new deliberative institutions. First, deliberation was made compulsory in some instances, but was in general expected to be organized voluntarily by the interested parties; some IMCs currently exist on paper only. Second, mandatory deliberation was restricted to specified matters, which were in most cases technical or executive. It did not usually affect the normative competences of regions, communities or the federal government, ${ }^{\text {, }}$ and was not intended to facilitate discussion of policy 
options. Although an IMC was allowed to conclude collaboration agreements 'for the creation and management of common institutions or services, the joint exercise of exclusive competences, or the development of joint initiatives'. most of the early agreements concerned merely the regulation of the transfer of national services to the communities or regions. Third, decision-making by consensus was accepted as the rule, and final decision-making power remained with the respective governments, which could reject agreements (as they have done on several occasions). Fourth, there were no provisions for democratic control. Instead. the respective governments carried full responsibility for their decisions and could be called to account by their parliaments or councils only in a formal sense.

Politics in this institutional framework was ambiguous. On the one hand, extensive exchange materialized at ministerial and bureaucratic level either within the deliberative structure or outside it. Practical politics often gave priority to the cooperative mechanisms in the Belgian federal model 'to keep things going'. On the other hand, more formal relations between federal and regional arenas remained to a large extent only partly developed. Sometimes exchange did not materialize (as in the area of external relations) or a partner backed out, immobilizing decision-making (as in the area of agricultural policy), or the partners decided to terminate cooperation on certain issues and possibly to leave them to a single level (as in the case of EC-structural funds, which the Flemish and Walloon region negotiate separately and directly with the EC). In these instances the partners emphasized the exclusive competences and autonomy of each arena, which were formalized by the model of dual federalism.

INSTITUTIONAL PERSISTENCE: THE CONSOCIATIONAL LEGACY AND TERRITORIAL SOLUTIONS

It is quite obvious that the contradictions in the formal federal model and in practical politics are related. More puzzling seems their resilience in each subsequent territorial model of nationalist conflict management. This last section argues that the consociational tradition in Belgian politics may be responsible for this.

\section{The Consociational Legacy}

Consociationalism in a narrow sense is a particular type of decisionmaking, whereby a decision is taken by consensus. This consensus is usually pursued by explicit rules: enhanced representation of recognized minorities, control of agenda by groups on issues of special interest (a 
form of ideological 'alarm bell'), mutual veto and special majorities, fixed distributive codes, institutions to allow groups to monitor execution of policies of special interest, decentralization and group autonomy. ${ }^{35}$ The broader meaning of consociationalism refers to the political regime where these rules are institutionalized and where they force the elites of the segments to reach decisions on major issues by consensus. ${ }^{*}$ Consociational democracies are characterized by the coexistence of 'sharp plural divisions and close elite cooperation' . ${ }^{37}$ Politics in Belgium has repeatedly been characterized as consociational, mainly in relation to the ideological cleavage between Catholics and non-Catholics.

The consociationalist literature usually puts forward elite accommodation as the crucial feature of a consociational regime. Only the segmental elites are able to overcome the deep cleavages between the segments. Another property is sometimes less emphasized: segments seek to maximise their independence or self-determination, and they have a restrictive interpretation.

Self-determination riay be understood as autarchy or autarky. A segment may be predominantly concerned with maximum control over production and allocation of the necessary goods and services in its realm. The bottom line is that it has the final say over the allocation of resources among its members. This positive description of self-determination would be labelled 'autarchy'. 'Autarky', however, adds defensive features to autarchy. It could be defined as those instances in which a segment is chiefly preoccupied with protecting its members and interests from external influences.

Autarchic and autarkic systems of self-determination can be expected to produce different political processes. More particularly, they have implications for the context and outcome of negotiations. First. the bargaining context is prescribed more restrictively under autarky than under autarchy. Under the former, matters under the control of a segment are in principle non-negotiable. Only topics from outside the segment can be used as bargaining chips: matters under joint governance with other segments. or issues not yet dealt with by segments (such as elements until then under exclusive control of the centre, or newly emerging issues). Autarchy is characterized by a more flexible bargaining context. The segment may in principle be willing to negotiate on matters within its realm. However, it will demand strict conditions. Bargaining partners must be on an equal footing and. above all, the segment will probably want to have the right to vote a deal down in the end (veto).

Second, the outcome of a bargaining process is likely to differ, especially with respect to the power balance between centre and segments. Under autarky rules, successful segments will almost always have 
gained ground at the expense of the centre: change tends to be unidirectional. For segments concerned with autarchy, a successful outcome may also mean that they have traded some of their less central assets for more relevant resources. The trade may be with the centre or with the other segment or segments; change is based on exchange. Thus the more a segment adds autarky to its pursuit of self-determination. the more restrictions are imposed on bargaining.

It is argued that consociational regimes in general show some traits of defensive self-determination. or autarky. This was so for the Catholic and non-Catholic pillars in Belgium: they performed well (autarchy), but were almost isolated from the external world (autarky). Elites tended to be most concerned with the domestic politics of their segment. Only when their segment became less cohesive would they be inclined to turn outwards to extract resources. Hence elites had few incentives to interact and even fewer to co-operate on a regular basis. They were also largely immune to sanctions calculated to force them to co-operate. ${ }^{* *}$.

The political process of elite interaction took on particular features. First. the elites sought to maintain their segments as self-contained blocks. Thus they tended to set up parallel and self-sufficient segmental structures rather than concurrent ones. Second, they rejected a central authority that was more than the sum of its parts. In fact. there was no real autonomous centre because it was governed jointly by the segmental elites. Third, each segmental elite was nevertheless tempted to occupy the centre because that would give it stable access to additional resources. In fact, this saved the centre. As long as domination of the centre remained attractive, the elites stopped short of attempts to deplete it. Fourth, the elites claimed equal and independent status for their segments. They tended to reject decisions in which they had not participated, and were inclined to avoid joint decision-making altogether. Fifth. what had been attained before was inalienable: a segmental elite would usually refuse to discuss acquired rights and could normally not be forced to be more flexible because of its independent status.

Therefore. elite accommodation fell short of elite co-operation. First. common decision-making was limited to a restricted number of major issues. More importantly, common decision-making was only 'consensual' in a very narrow sense. It indicated that the decision rule was unanimity in most instances. But it did not imply a co-operative decision style. A distinction is usually made between three decision styles: maximization of one's own gain. maximization of one's relative gain compared to other actors. or maximization of the joint gains of all actors. Only the latter is co-operative or integrative. ${ }^{14}$ At first sight, the style of actors in the Belgian consociational setting could hest be described as maximiza- 
tion of their own gain. This would mean that they were basically indifferent to the pay-offs achieved by the other side. However, when taking into account the restrictive conditions outlined above the bargaining style seems to move closer to the competitive style, because actors did compare pay-offs. Put simply, each segmental elite wanted to be sure that the other would not get more out of the process than itself. Thus a segmental elite would want to have a veto (autarchy), it would refuse to negotiate over already acquired goods (inalienable autarky), it would not accept asymmetrical decisions (full reciprocity), and it would want to make a deal on neutral terms (equal status). There was little room for actual exchange: goods for bartering had to come from outside the segments. The consociational rules, which were partly formalized in laws or constitutional provisions, expressed these vested interests and sanctioned decision-making accordingly.

This had two consequences. First, the parties' prior concern was observance of the rules: how the deal was negotiated (the process). The content came only second: what was exchanged (the substance). Ultimately, nearly everything could serve as a bargaining chip as long as the rules of the process were observed. In pre-federal Belgian politics two techniques for conflict management were prevalent. One was package deals: each segment obtained something which had high salience for itself. There was often no policy connection between the items in the package. Package deals were usually made at the cost of the national treasury ('waffle-iron politics'). Another technique was to assign jurisdiction to groups over issues of concern to them. Policy functions that were state functions in most other countries were performed by segmental organizations for their segment only. "The result was that state autonomy was restricted and the autonomy of the social segments was enhanced. Thus the elites bartered national taxes and national state autonomy for less conflict.

Second, elites found it more rewarding in a consociational regime to be intransigent than cooperative in a great number of situations. Using game-theory. Tsebelis showed that consociational features reduced the negative consequences of disagreement, because they made it possible to postpone open conflict." Suppose a matter needed to be decided by a special majority, say two-thirds. If opponents and proponents were approximately equally strong, each conflict about the matter would have only theoretical significance. Matters would become serious only when one actor approached the special majority requirement, because that actor would be in a position to push forward a decision. Each actor would have to make up its mind whether it would co-operate or not. Thus stringent decision rules enabled actors to remain intransigent much 
longer than under flexible rules and therefore made co-operation and compromise less likely.

\section{Regionalism and Federalism}

The consociational legacy has been influential. The core consociational features were tried out on the ethnolinguistic cleavage, and were constitutionally entrenched in 1970 . They seem to have played a role in ethnolinguistic politics similar to that in ideological politics. On the one hand, they have facilitated elite accommodation when interaction was inescapable. Hence the introduction of linguistic distribution codes in such areas as public service recruitment or public procurement turned many daily decisions, which could otherwise be conflictual, into routine matters. Similarly, the special majority requirements for specific legislation took away the appetite of the Dutch-speaking group for any attempt to dominate the Francophones and instead encouraged accommodation. On the other hand, the mechanisms have made elite co-operation less likely: they have actually strengthened both the self-sufficiency and the sovereignty of the linguistic groups or their elites and have enabled them to exploit the centre. The greater the extent to which Dutch and French groups became distinctive, the more exclusive the dependence of the Dutch- and French-speaking elites on their own linguistic groups. This creeping 'de-Belgianization' or regionalization of the elites revealed itself very clearly in the split of the national parties along linguistic lines. The Christian Democrats broke up in 1968. two years ahead of the constitutional entrenchment of certain key consociational principles. The Liberals and Socialists followed suit in 1970 and 1978 respectively.

Consociational mechanisms put the unitary state to the test because they were to a large extent responsible for the regionalization of the elite. This paved the way for territorial solutions, at least indirectly. A classical consociational regime tries to keep conflict low by restricting the role of the state. Decision-making is passed on to the social segments. This logic of devolution to the associational level fits ideological and purely linguistic conflict well, but it does not fit nationalist conflict at all. Nationalists demand instead maximum control over symbolic and distributive functions of the state in order to shape or safeguard a national community. The power of a modern state relies upon its control over a fixed territory, where it can perform these functions. Thus nationalists need territory. Therefore, purely consociational mechanisms can not meet the interests of the regionally-oriented elites; territorial solutions are required.

However, territorial techniques to manage nationalist conflict have not simply replaced consociational solutions. Elite accommodation in regionalized or federalized Belgium has inherited many characteristics of 
the consociational regime. This helps to explain the ambiguity of centrifugal and centripetal tendencies in subsequent territorial models, includ. ing the most recent federal ones. Thus the national level is governed by regional elites which have a de facto veto (no autonomous national level); regional autonomy is jurisdictional (autarchy); federalized matters should, at least formally, not be questioned anew (inalienable autarky); deals must contain something for all partners (full reciprocity); and no deal can be made on the terms of one partner only (equal status).

This has consequences similar to those of consociationalism. First, the stringent rules of equilibrium must be observed strictly. The actors in the federal model tend to pay more attention to the process of conflict management (were the rules observed?) than to the outcome in terms of content. The typical bargaining chips in federalized Belgium are competences, which are shifted from the centre to regions and communities. But these are precious chips, because the autarky rule makes it difficult to shift them back from regions and communities to the centre. A less costly technique for conflict management is to use legal provisions or normal democratic procedure as bargaining chips: the actors agree to stretch existing rules temporarily to their mutual convenience.

In other words, they make a sort of package deal to overcome deadlock. A conflict of interest between regions, communities and the federal government concerning a salary increase for civil servants was managed along these lines in November 1991. Regions and communities risked running into great financial difficulties if they honoured commitments to their respective civil services. The matter remained pending in the Deliberation Committee for months. Ultimately, they were allowed to depart from certain provisions concerning the employer's social security contributions. Moreover, the Francophone community and Walloon region on the one hand and the Flemish community on the other hand were both granted exernptions, though from different provisions. Although the departure from normal procedure was said to be onceonly, it raised great concern in the private sector. From a citizen's perspective, this practice risks creating legal and democratic insecurity and may cause political alienation. From the perspective of the main political actors in the interethnic games, it seems preferable to a formal devolution of competences because it leaves the state structure unaltered. Infinite devolution of competences has a clear ultimate end: secession.

However, the end of the Belgian experiment need not take place in the immediate future. The second consequence explains why: the stringent rules for decision-making tend to postpone decision-making on these terms. If one party wants to transfer competences to its region, it will 
usually have to initiate a demanding revision procedure culminating in a two-thirds majority vote in parliament (and sometimes additionally an absolute majority in each language group). In other words, a decision requires quasi-unanimity among the major actors. An actor will usually need a long time and side-payments to other actors to accumulate such a majority. In the meantime, the issue is likely to be put on ice.

\section{NOTES}

1. This account is largely based on L. Hooghe, A Leap in the Dark: The Bclgian Federal Reform (Ithaca. NY: Cornell University Occasional Papers of Western Societies Program. No.27. 1991).

2. In 1893 suffrage was extended to all male citizens. but its democratizing effect was tempered by a system of plural voting based on educational and economic status.

3. The secular state was contested hy one part only of the Catholic Party.

4. For an analysis of the social bases of early Flemish nationalism see M. Hroch, Die Vorkämpfer der nationalen Bewegungen bei den kleinen Völkern Europas: eine ver. gleichende Analyse zur gesellschafilichen Schichtung der patriotischen Gruppen (Prague: Universita Karlova Praha. 1968). pp. 103-12. Hroch categorized the Flemish nationalist movement among the unsuccessful cases, because it did not develop into a mass movement.

5. See B. Anderson, Imagined Cummunities (London: Verso. 1991).

6. The Flemish nationalists tried to build a fourth pillar (zuil) next to the christian. socialist and liberal zuilen in the interwar period. but the repression of Flemish nationalism immediately after the Second World War thwarted these efforts. Hellemans defined a zuil as an idenlogical and subcultural. integrated network of several (more than two) organizations that are task-specific and enjoy a monopoly in the movement. One of these organizations is a political party: see S. Hellemans, Pleidooi voor een internationale en regen een provincialistische benadering van verzuiling (Leuven: K.U. Leuven. Sociologisch Onderzoeksinstituut. 1990). p.26.

7. Infants were either classified in the language group of their parents or not counted at all: K. McRae, Confict and Compromese in Multilingual Societies: Belgium (Waterloo: Wilfrid Laurier Press, 1986). pp.36-7.

8. McRae. op. cit., p.40.

9. Ibid.. pp. 276-85.

10. For a discussion of alternative measurements see $M$. De Metsenaere. 'De taalverhoudingen sinds Hertoginnedal'. Taal en Sociale Integratie: het probleem Brussel sinds Hertoginnedal (1963) (Brussels: VUB-Press, 1990). pp.37-57.

11. This decision was taken by the Provisional Government. which was formed after the secession, on 16 October 1830.

12. See H. Elias, Geschiedenis van de Vlaamse gedachie, 4 vols. (Antwerp: De Nederlandsche Boekhandel. 197(1-1971).

13. See P. Berckx. ISO jear institutionele hervormingen in Belgiē (Antwerp: Kluwer Rechtswetenschappen. 1990).

14. The official Dutch version of the Belgian Constitution obtained legal force under the law of 10 April 1967.

15. McRae. op. cit. p. 278.

16. W. Dewachter, 'Elite-circulatie en maatschappelijke ontvoogding. De Belgische elite tegenover de Vlaamse Beweging. "Tijdschrifr voor Sociologie. Vol.11. Nos.3-4 (1981). pp. $199-258$.

17. These were incorporated in the Belgian constitution in 1970.

18. In the elections of November 1991 the party cuncentrated its campaign on four issues: 
repatriation of non-European immigrants. Flemish separatism, traditional Christian values (and. specifically, opposition to abortion), and a demand for high moral standards in political life.

19. L. Genicot (ed.). Histoire de la Wallonie (Toulouse: Univers de la France et des pays francophones. 1973): H. Hasquin, Historiographie et politique: essai sur l'histoire de Belgique et la Wallonie (Charleroi: Institut Jules Destrée, 1982); C. Kesteloot. -Strategies wallonnes et francophones à Bruxelles'. Taal en sociale integratie (Brussels: VUB, 1982). pp.445-80.

20. M. Quevit, Les causes du déclin wallon (Brussels: Editions vie ouvrière. 1978).

21. Kesteloot, op. cit., pp. 448-80: J. Tyssens, 'De Mouvement populaire wallon en de kwestie Brussel (1961-1964)'. Taal en sociale integratie (Brussels: VUB, 1989), pp.373401.

22. Statistics from: NIS. Statistische Studiēn (Brussels: NIS), No.32 (1973); No.55 (1979); No.91 (1991).

23. For the Brussels situation see especially the series Taal en Sociale integratie from the Centrum voor Interdisciplinair Onderzoek van de Brusselse Taaltoestanden, Vrije Universiteit Brussel.

24. Parlementaire Handelingen, Senate, 1969-1970, 18 Feb. 1970, pp.777-8.

25. In the meantime the central public service was increasingly reorganized along language lines. The public service creased unilingual working units where appropriate in the 1930s. It also adopted a division of labour along language lines: for instance, Dutchspeaking public servants usually dealt with dossiers originating in the Dutch language area or drawn up in Dutch. This strategy was generalized in the 1960s and 1970s. The evolution was most drastic for the ministry of education and culture, which in 1963 was entirely restructured along language lines. In 1966 the two 'wings' drew up separate budgets for the first time. In 1969 a French and a Dutch ministry of education and culture were established. Due to the regionalization (semi-federalization) of 1980 , cultural policy was almost completely transferred to the communities; the administrative units for cultural matters were subsequently regionalized. The two national ministries were slimmed down to the ministry of Dutch-speaking education and the ministry of French-speaking education. Finally, in 1989 these two ministries were transferred to the Flemish and Francophone communities respectively. Note that the actual splitting up in the 1960 s preceded the first major move towards regionalization in 1970.

26. Berckx. op. cit.. p. 150.

27. The Brussels region obtained no separate institutions. The parties could not make a ciear-cut choice between the bipartite or tripartite model. They left Brussels in brackets. that is. a sub-cabinet within the national government took care of the regional affairs of Brussels. The institutions of the Flemish region were merged with those of the Flemish (previously Dutch) community.

28. The third path was the national arena, where rules for linguistic parity in parliament, cabinet, national public service and most policy areas protected the linguistic groups.

29. The nationality principle did not mean that the communities had no territorial boundaries. Territorial delineations were fairly unambiguous; only in Brussels could persons or institutions choose their community adherence. To the Flemish community belonged the citizens of the Flemish region (including those who did not speak Duteb) and the Dutch-speakers in the Brussels region. The French community united the citizens of the Walloon region (including those who did not speak French) and the Francopbones in the Brussets region. The German community consisted of a limited number of predominantly German-speaking municipalities in the east of the country. It was part of the Walloon region for regional matters.

30. D. Heremans and P. Van Rompuy. 'Economische beleidsautonomie voor Vlaanderen in het Europa van morgen', in P. Van Rompuy (ed.), Vlaanderen op een kruispunt: sociologische, economische en staatsrechierlijke perspectieven (Tielt: Lannoo, 1990), pp.152-74.

31. Competences for the communities included culture, language policy, education, health 
and welfare policy (except for social security related matters), and international cooperation in these areas. Competences for the regions included regional economic development (such as employment programmes and industrial restructuring), environ. ment, nature conservation, land-use planning and urban renewal, water resources and sewage. public housing. aspects of energy policy. local government, infrastructure (including harbour policy), road building, waterways, regional airports and public local and regional transport.

32. The financial system is complex. Roughly half of the budget for regions and communities, predominantly the education budget. comes from grants. It is linked to the evolution of the pupil population. The other half comes from a share of the personal income taxes plus a limited amount of regional or community taxes. The tax-sharing system works as follows: the total basic transfer (the amount spent before federalization) was fixed in the financial law of 1989. It is adjusted yearly to the GDP growth rate and subsequently divided among regions and communities according to their share in taxes. Regions may raise surcharges on national taxes (or allow tax rebates) from 1994 onwards. An agreement to move this possibility forward to 1992 and to extend it to the communities was not carried out before the cabinet resigned in October 1991.

33. The committee consists of a six-member federal delegation headed by the prime minister and containing an equal number of Dutch and French speakers: two members of the Flemish executive (which represents both region and community). including its president: the presidents of the Walloon regional executive and of the Francophone community executive: and the French-speaking president and a Dutch-speaking member of the Brussels regional executive. The German community does not have a permanent seat. but takes part as a voting member on matters of concern to it.

34. An exception is that communities. regions and the federal government were required to discuss the government revenue budget.

35. M. Covell. 'Ethnic Conflict and Elite Bargaining: The Case of Belgium'. West European Politics. Vol.4. No.3 (1981). pp.197-218.

36. J. Obler. J. Steiner and G. Dierickx. Decision-making in Smaller Democracies: the Consociational Burden (London: Sage, 1977).

37. A. Lijphart. Democracy in Plural Societies (New Haven. CT: Yale University Press. 1977). p.2. The original idea of 'consociatio' as developed by Althusius was quite different. For the origins of the concept see T.O. Hüglin. Sozieialer Föderalismus. Die politische Theorie des Johannes Althusius (Berlin: Walter de Gruyter. 1991). pp.133th.

38. For an analysis of elite strategic behaviour in a consociational system applying game theory, see G. Tsebelis. 'Elite Interaction and Constitution Building in Consociational Democracies. Journal of Theoresical Politics. Vol.2. No.1 (1990). pp.5-29.

39. F. Scharpf. 'Decision Rules. Decision Styles and Policy Choices'. Journal of Theoretical Politics. Vol.I. No.2 (1989). pp.1+9-176.

40. The state subsidized the expansion of Catholic education. which is managed by the Catholic church. Social security is to a large extent administered by Catholic and socialist segmental organizations.

41. Tsehelis. op. cit.. p.22. 